\title{
BIM ADOPTION IN THE AEC/FM INDUSTRY - THE CASE FOR ISSUING BUILDING PERMITS
}

\author{
Kaleem ULLAH ${ }^{*}$, Christopher RAITVIIR, Irene LILL, Emlyn WITT \\ Building Lifecycle Research Group, Department of Civil Engineering and Architecture, Tallinn University of \\ Technology, Ehitajate tee 5, 19086, Tallinn, Estonia
}

Received 01 May 2020; accepted 06 August 2020

\begin{abstract}
BIM adoption is a complex process and relatively little information exists on the BIM adoption processes of public authorities. This research aims to address this gap by examining how a contemporary public authority is approaching BIM adoption for their building permitting process. Firstly, a systematic literature review was carried out to understand extant descriptions of BIM adoption processes and the factors affecting adoption success. This resulted in the derivation of a generic BIM adoption process and the classification of factors that affect BIM adoption with reference to the Technology Organization and Environment (TOE) framework. The case of the BIM adoption process and the factors affecting its implementation in a contemporary public authority were then analysed in terms of the generic adoption process and factor classification derived from the literature. The findings reveal the planning strategies and execution steps for BIM adoption and the factors affecting them. This study provides a systematic approach to investigating BIM adoption in a public authority. It contributes to the understanding of BIM adoption processes and factors affecting them and is anticipated to be useful for AEC/FM professionals in understanding and facilitating successful BIM adoption.
\end{abstract}

Keywords: Building Information Modelling, AEC/FM industry, BIM adoption, building permits, public authorities, systematic literature review, case study.

\section{Introduction}

Construction projects normally require a building permit from a regulatory authority, and it can be considered as an important milestone for projects. Typical building permitting procedures are complicated, unclear, error prone and inefficient (Eirinaki et al., 2018; Nawari \& Alsaffar, 2017) so that building permits are subject to delays in processing and issuing. Building Information Modelling (BIM) as an innovative technology has changed the way construction projects are conceived, designed, constructed and operated (Husain et al., 2018; Hardin, 2009) and is widely recognized as having the capacity to improve project performance (Franz \& Messner, 2019; Whyte \& Hartmann, 2017). BIM can be beneficially leveraged for several purposes e.g. design and construction integration, cost estimation, scheduling, coordination, energy simulation, safety, and facility management. This study concerns the potential for BIM use in the building permit process.

A building permit is a document issued in the form of an administrative decision which gives legal permission for the commencement of construction works in accordance with the appropriate laws, regulations and codes (Krajewska et al., 2014; Leśniak et al., 2019). The issuance of a building permit is an important step for any construction project (International Code Council, 2018). Building permits can influence spatial property development, as they prevent undesirable developments which are not in compliance with the city planning (Samsura et al., 2015; Eika, 2019). The building permitting process is also an important component of the institutional factors that significantly influence the success of construction projects (Gudienè et al., 2013, 2014) and the number of building permits issued is a key indicator in microeconomic fundamentals (Meulen et al., 2014) and of construction sector performance (Kildiené et al., 2011). In a typical building permitting process, if a property owner or developer decides to apply for a building permit, it requires filling in various forms and providing different supporting documents. For the public authority, it requires checking the submitted application and associated files against various codes and regulations and requires coordination among various departments. It is therefore a time-consuming, difficult to track process subject to errors (Eirinaki et al.,

${ }^{*}$ Corresponding author. E-mail: kaleem.ullah@taltech.ee 
2018). This calls for digitalization that could improve the efficiency of the building permitting process and BIM has the potential to simplify and automate the process if it is adopted by the regulatory authorities that deal with building permits (Nawari \& Alsaffar, 2017; Olsson et al., 2018).

A few existing studies, including those by Nawari and Alsaffar (2017), Olsson et al. (2018) and Narayanswamy et al. (2019) have addressed BIM use for building permits. These have referred to BIM capacity for building permits and investigated automated code checking procedures. There is, however, a lack of studies that systematically show the BIM adoption process by public authorities or organizations responsible for building permits. The BIM adoption process (the actions that should be taken in adopting BIM) is an important aspect as the outcomes of BIM usage are reliant on the quality of the adoption process (Gurevich et al., 2017). Thus, there is a significant need to investigate the BIM adoption process by public authorities dealing with building permits and the aim of this paper is to do so.

In contrast to the limited academic research on the BIM adoption of public authorities, there are numerous studies concerning BIM adoption in the AEC/FM industry generally and these can be drawn on to derive a framework with which to investigate and understand the BIM adoption process of public authorities and their building permitting processes.

This research therefore commences with a systematic review of the literature regarding BIM adoption and the factors that affect it. From the extant literature identified, a generic BIM adoption process is derived as is a classification of factors that affect BIM adoption. Together, these provide a framework with which to investigate the BIM adoption process in a specific case - that of the Tallinn City Government (TCG) which is the public authority responsible for processing and issuing all building permits in the Estonian capital city, Tallinn.

A description of the literature review and case study methodology follows in section one. An overview of the BIM adoption literature is presented in section two and the generic BIM adoption process and classification of factors affecting BIM adoption which emerge from the synthesis of the literature are described in section three. Within the framework of this generic process and classification, the TCG case study is carried out and it is presented in section four. Conclusions and recommendations are then drawn in the final section.

\section{Methodology}

A literature review was first carried out in order to identify the various contemporary views on BIM adoption and the observed and theorised BIM adoption processes in the AEC/FM industry as well as the factors that influence these. The data from the literature were then synthesized into a generic BIM adoption process and factor classification system which could be used as a framework with which to analyse the BIM adoption process with respect to a specific, current case of a public authority (that of TCG). The case study was then undertaken and reported in accordance with the derived analytical framework.

Kitchenham and Charters (2007) defined systematic literature review as "A form of secondary study that uses a well-defined methodology to identify, analyse and interpret all available evidence related to a specific question in a way that is unbiased and to a degree repeatable". The systematic literature review process applied in this case was inspired by that of (Gough, 2007) and described in nine steps by Bearman et al. (2012) as follows:

1. Formulating the review question - in our case: What are the existing BIM adoption processes in the AEC/FM industry and what factors affect them?

2. Determining inclusion and exclusion criteria: Only relevant journal and conference papers published in English were considered with no geographic limitation and no restriction on year of publication.

3. Establishing the search strategy, including information sources: The Boolean phrase: ("Building Information Mode?1*" OR "BIM") AND ("Adoption" OR "Implementation") was used and the following online databases were searched:

- Scopus;

- Web of Science (Clarivate Analytics);

- ASCE Library;

- EBSCOhost Web;

- Science Direct;

- Emerald Insight.

4. Screening the articles to check whether they meet the inclusion and exclusion criteria: Titles and, where necessary, abstracts were screened for relevance to review question. The Mendeley Reference Manager was used to identify and remove duplicated articles.

5. Reporting the results of the search strategy. Table 1 shows the results of the search and screening.

Table 1. Number of articles returned from online databases

\begin{tabular}{|l|c|c|}
\hline \multicolumn{1}{|c|}{ Databases } & $\begin{array}{c}\text { Articles returned } \\
\text { from databases } \\
\text { search }\end{array}$ & $\begin{array}{c}\text { Relevant } \\
\text { articles after } \\
\text { screening }\end{array}$ \\
\hline Scopus & 2055 & 181 \\
\hline Web of Science & 1316 & 153 \\
\hline EBSCOhost Web & 718 & 105 \\
\hline ASCE Library & 1322 & 52 \\
\hline Emerald Insight & 821 & 36 \\
\hline Science Direct & 407 & 30 \\
\hline $\begin{array}{l}\text { Overall (with duplicates } \\
\text { removed) }\end{array}$ & N/A & 319 \\
\hline
\end{tabular}

6. Extracting relevant data: The relevant articles were exported to NVivo Plus (v.12) software from Mendeley Reference Manager and subjected to qualitative content analysis. 
7. Evaluating the quality of the included studies: Quality was considered adequately ensured through the status of the included articles as being published in peer reviewed journals and conference proceedings that are indexed in reputable databases.

8. Synthesising the collective evidence of the included studies to answer the review question: The evidence regarding BIM adoption processes and factors affecting them was synthesised using a qualitative procedure of identifying relevant content of the selected articles and coding them according to emergent themes (for example: process stages and factor types). This process was carried out using NVivo Plus (v.12) and the generic BIM adoption process and classification of the factors that affect it are presented in section 2 below.

9. Drawing conclusions and communicating the findings.

Gerring (2004) defined case study as "an intensive study of a single unit with an aim to generalize across a larger set of units". Case study is a strategy that seeks to explain and offer rich information about a particular contemporary phenomenon within its context, typically through a number of data collection methods including interviews, questionnaires, observations, document analysis, and others (Robson, 2002). However, according to Almuntaser et al. (2018) the limitation of case study is that it cannot be used to make generalizations. The data collection methods employed in the TCG case study for this research were interviews with TCG officials, content analysis of TCG reports and documents and participant observation in TCG meetings by one of the co-authors who has been embedded with TCG in order to understand their processes and help develop a BIM-enabled building permitting process. Specifically, face-to-face interviews were carried out with 5 TCG officials and participation in 15 group meetings held by TCG regarding BIM adoption. All the interviewees had more than 10 years of experience in the field. The findings from the case study are reported through analysis of interviews and content analysis of the reports and documents from TCG. The case study data were analysed and reported on the basis of the analytical framework developed from the literature and the results are presented in section 3 .

\section{The AEC/FM industry BIM adoption literature}

\subsection{Theoretical perspectives on BIM adoption}

There is a general consensus in the literature that BIM adoption is a social phenomenon. Various social theories, frameworks and models have been used for examining BIM adoption processes and the factors that influence them. The most common theoretical perspectives applied were found to be: Diffusion of Innovation Theory and the Technology Acceptance Model. Other theoretical perspectives adopted included: Institutional Theory, Task Technology Fit, Theory of Reasoned Action, Theory of Planned
Behaviour, and Unified Theory of Acceptance and Use of Technology. Diffusion of Innovation (DOI) theory is the most widely used theory to explain IT and BIM adoption (Hameed et al., 2012; Ahmed \& Kassem, 2018). DOI theory was proposed by Everett Rogers in 1962 and explains how new ideas (innovations) move through a particular social system. It suggests a five-stage process for diffusion of an innovation which includes awareness, interest, decision, implementation, and confirmation (Rogers, 1983). In the literature reviewed, it was used for investigating the BIM adoption process e.g. by Gledson and Greenwood (2017), for digital innovation (BIM) diffusion e.g. by Shibeika and Harty (2015) and for factors affecting BIM adoption e.g. by Xu et al. (2014).

The Technology Acceptance Model (TAM) proposed by Davis (1989) explains the behaviour of users in acceptance of information technologies. TAM has two key perceived attributes namely "Perceived Usefulness" (PU) and "Perceived Ease of Use" (PEU). PU refers to "the degree to which a person believes that using a particular system would enhance his or her job performance", while PEU is "the degree to which a person believes that using a particular system would be free of effort" (Davis, 1989). Among the studies reviewed in this research, TAM was primarily used for identifying factors influencing BIM adoption e.g. by Sanchís-Pedregosa et al. (2020) and Qin et al. (2020).

\subsection{AEC/FM industry BIM adoption processes}

In this research, "BIM adoption process" refers to the actions, techniques, methodologies or steps undertaken by stakeholders in order to adopt BIM in their organization$\mathrm{al} /$ project contexts. In the literature review, a lack of studies systematically describing the BIM adoption process by public authorities or organizations responsible for building permits was observed. However, specific BIM adoption processes have been proposed by various authors in the AEC/FM industry.

Hochscheid and Halin (2019) described the BIM adoption process as a five-stage process, based on Roger's Diffusion of Innovation theory. The first stage, Awareness, occurs when an organization is exposed to or becomes aware of BIM. In second stage, Intention, the organization starts seeking further information about it. The decision stage refers to the organization deciding whether to adopt or reject BIM. During Implementation, BIM is utilised, and, in the Confirmation stage, the organization has started using BIM and confirms its commitment to continue its use.

Almuntaser et al. (2018) developed a BIM adoption framework based on the case study of an architectural firm in Saudi Arabia. Their framework draws on the Project Management Institute Standards Committee (2013) five project management processes as follows: Initiating: the organization's vision, objectives, deliverables and milestones for BIM adoption are defined, a BIM team is selected, all stakeholders are identified, and financial resources 
are provided. Planning: Different areas for BIM implementation are selected, the scope of work to be carried out for BIM adoption is defined, potential risks and quality assurance measures are identified, procurement is planned and effective communication between all stakeholders is established. Executing: This phase includes creation and coordination of the BIM model between all disciplines. Monitoring and controlling: Monitoring BIM adoption to ensure that the objectives are being achieved within the set time and cost and BIM deliverables are within the scope defined. Closing: The last phase involves handovers of all deliverables and measuring BIM performance in the organization, the project and the team for improvement.

Based on a literature review Kouch (2018) developed a three step BIM implementation framework consisting of understanding, planning, and piloting. Understanding includes gaining BIM knowledge, developing strategies for short-term and long-term goals, financial support for BIM implementation, addressing challenges and assigning BIM teams. In the planning step, the BIM teams analyse the current process of activities and resources (human, tools, etc.) in order to develop new, BIM-based processes. Kouch (2018) states that during planning the available standards and guidelines for BIM implementation can also be considered. Piloting is a practical step implementing what is planned and includes model creation, monitoring and control, and handover.

Ahn et al. (2016) illustrated BIM adoption process through case studies of four construction companies in the USA. The process starts with hiring BIM experts and selecting areas for BIM implementation. Investing in BIM software and hardware. Developing a BIM implementation plan and strategies for collaboration with subcontractors and design teams. Based on the BIM implementation plan and guidelines, an organization can begin BIM implementation for real projects. Once BIM implementation has been incorporated in the work process, the next step is the coordination with other stakeholders for maximizing the benefits of BIM implementation. The BIM adoption process presented by Ahn et al. (2016) also includes BIM education and training of organization employees.

Machado et al. (2016) presented a rational, 5-stage approach to BIM implementation in a UK-based SME. In the first stage, establishing best practice knowledge in BIM: a literature review determined best practices of BIM in the UK and semi-structured interviews were conducted to explore the drivers, steps for implementation and the challenges of BIM implementation. The second stage, review and analysis of the organization's current situation: the organization's current business processes and workflows were reviewed to understand ICT systems and infrastructure, file formats and information exchanges used in the organization and thus identify the areas where BIM could be used for supporting the organizational objectives. Stage three, developing BIM-based collaborative strategy: This stage included analysing improvement gains, determining required IT systems, formulating a training plan for employees and developing the organizational BIM im- plementation strategy. Stage four, implementation of BIM based strategy: includes the deployment of a BIM pilot project to put in practice the new business process which was planned. Finally, stage five: Project review, evaluation, and dissemination: which includes the assessment of the project on which BIM was used.

Hochscheid and Halin (2018) examined BIM implementation in various architecture firms. The BIM implementation approach consisted of four steps: Firstly, Context study: reviewing the organization's current situation and practices. Planning: developing new business processes and a strategy for BIM implementation. Execution: piloting BIM implementation based on the developed strategy. Transfer: the fourth and final step in which the pilot project is assessed with the aim of further improving BIM use.

Arayici et al. (2011) studied BIM adoption in an architecture firm through case study. The BIM adoption process proposed by Arayici et al. (2011) comprises four stages: firstly, reviewing and assessing the current practices of organization and identification of benefits from BIM implementation; secondly, designing a new business model and documentation of the BIM implementation path. The third stage is the actual implementation of BIM and it also includes piloting BIM implementation on projects and training the employees. The final stage is the evaluation of the project aimed at assessing the net benefits from it.

A roadmap for implementation of BIM was presented by Khosrowshahi and Arayici (2012) from the results of a questionnaire survey amongst contractors in the UK. Before the questionnaire survey, interviews were carried out with construction professionals from Finland to determine BIM implementation best practices. The BIM implementation roadmap comprises identifying challenges in BIM implementation, developing an effective strategy for implementing BIM and providing professional guidelines to BIM adopters.

To support decision making in BIM adoption, Gu and London (2010) developed a Collaborative BIM Decision Framework. The developed Collaborative BIM Decision Framework consists of four parts. Part 1: defining scope, identifying purposes, establishing roles, extent of BIM and map to project phases. Part 2: Developing work process roadmaps within and across organizations. Part 3: Identifying technical requirements of BIM. Part 4: Collaborator capabilities evaluation.

The literature also revealed existing elaborations of certain parts of the BIM adoption process. For example, Chunduri et al. (2013) developed three procedures for assisting facility owners in BIM adoption planning through literature review and case studies. The procedures consist of BIM organizational strategic planning, BIM project procurement planning, and BIM organizational execution planning. In strategic planning, an organization assesses their status and needs, sets objectives and goals and determines the area of focus for BIM implementation. Procurement planning includes the development of a well-defined 
BIM contract language for achieving the goals and objectives, team selection, contract procurement and execution requirements and execution planning provides implementation guidance for BIM implementation.

Lin et al. (2016) developed a detailed BIM execution plan for BIM implementation in Facilities Management (FM) consisting of seven core elements: 1) establishment of team for BIM-FM implementation, 2) development of a strategy for successful BIM implementation, 3) developing BIM-FM documents which show areas for BIM implementation and management of the BIM model, 4) development of the BIM-FM process which includes describing the current processes, designing new BIM processes, and developing transition processes for achieving BIM usage, 5) formation of BIM-FM information collection which shows the information needs of the organization and the information to be displaced and integrated with the BIM model, 6) development of inspection mechanism for BIM models and 7) development of rules for BIM model usage in FM.

\subsection{Factors affecting BIM adoption}

BIM adoption factors are the determinants which can enable or inhibit the adoption of BIM in an AEC/FM industry organization. The literature review showed that numerous academic enquires from many different countries have already been made (predominantly using questionnaire surveys) to identify factors that affect BIM adoption. Factors influencing BIM adoption are generally similar, but a difference in their impact level can be observed among countries (Kim et al., 2016).

Through questionnaire surveying of BIM experts in China, Ma et al. (2019) studied BIM adoption influencing factors. They concluded that project leadership and software functionality are two fundamental factors influencing BIM adoption as they also affect the other factors directly or indirectly. Gledson and Greenwood (2017) investigated 4D BIM adoption in the UK construction industry through a questionnaire survey among construction planning practitioners and found that the relative advantage of BIM is the most prominent factor for 4D BIM adoption. According to Eadie et al. (2013) applications offered by $\mathrm{BIM}$ and client or competitive pressure were the main factors driving BIM adoption in UK contractors. Son et al. (2014) surveyed the factors influencing BIM adoption in South Korean architecture firms and found that the primary influencing factor was top management support. Kim et al. (2016) and Lee and Yu (2017) also investigated factors influencing BIM acceptance in the South Korean construction industry. In India, Ahuja et al. (2016) studied factors impacting BIM adoption and concluded that expertise, trialability, and management support were the most critical factors. Based on a qualitative and quantitative approach, Hong et al. (2016) explored factors affecting BIM adoption decisions in small and medium size construction organizations (SMOs) in Australia. Awareness and innovativeness were among the main factors influencing the BIM adoption decision.
Different typologies were found to be used by researchers for factor classification. Ma et al. (2019) classified factors influencing BIM adoption into institutional and technology factors. Liao and Teo (2019) grouped the factors according to people, process, technology, and external environment aspects. Hong et al. (2016) categorized influential factors for BIM adoption in three groups: adoption motivation, organizational competency, and ease of implementation. $\mathrm{Gu}$ and London (2010) grouped the factors affecting BIM adoption into technical and non-technical areas.

\section{Analytical framework derived from the literature}

The findings from the literature review in terms of observed and proposed BIM adoption processes in the AEC/ FM industry were then synthesised into the generic BIM adoption process shown in Table 2. This draws together and organises all of the detailed process steps described in the extant literature and frames them in a four-stage process of initiation, planning, execution and evaluation. It is important to note that, although this has the appearance of a simple, linear process, the authors acknowledge that BIM adoption does not necessarily take place in a simple, linear fashion and, indeed, some of the literature specifically points this out, e.g. (Whyte \& Hartmann, 2017).

Similarly, the factors identified during the literature review have been collated and categorized in Table 3 using the Technology, Organization and Environment (TOE) framework for adoption of innovation developed by Tornatzky et al. (1990). The technological context encompasses both internal and external technologies connected to the organization and includes the characteristics of technology to be adopted. The organizational context refers to the characteristics and resources of the organization in which the technology will be adopted. The environmental context includes the industry, the organization's competitors and the regulators that shape the macro environment in which that organization exists.

Tables 2 and 3 thus provide a generic framework based on the literature with which to analyse the BIM adoption process for the purpose of issuing building permits taking place within the case study organization (TCG) and the factors that are affecting it.

\section{Case study}

\subsection{The case study organization: Tallinn City Government}

In this case study, the BIM adoption process by a municipal public authority, Tallinn City Government (TCG) was investigated. TCG has two major roles in the AEC/FM industry: it is a public authority as the issuer of building permits, certificates of occupancy and demolition permits. It is also a client through its real estate department responsible for managing construction projects owned by TCG, but this client role is beyond the scope of this case study. 
Table 2. AEC/FM industry BIM adoption process

\begin{tabular}{|c|c|c|c|c|c|c|c|c|c|c|c|c|}
\hline 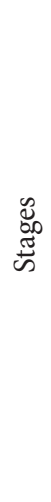 & Detailed steps & 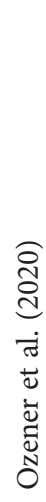 & 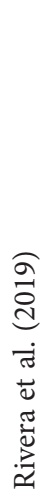 & 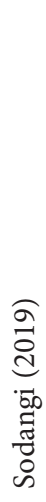 & 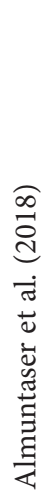 & 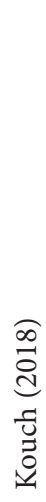 & 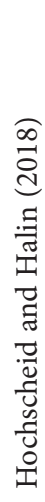 & 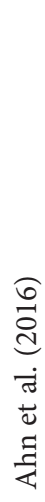 & 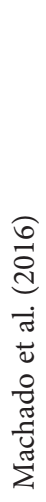 & 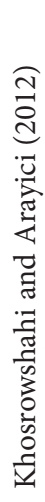 & 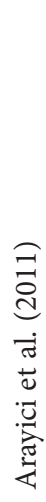 & 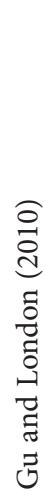 \\
\hline \multirow{12}{*}{ 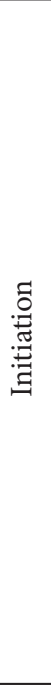 } & $\begin{array}{l}\text { Reviewing organization current situation and } \\
\text { practices }\end{array}$ & & $\checkmark$ & & & $\checkmark$ & $\checkmark$ & & & & $\checkmark$ & \\
\hline & $\begin{array}{l}\text { Defining objectives of the organization for } \\
\text { adopting BIM }\end{array}$ & $\checkmark$ & $\checkmark$ & & $\checkmark$ & $\checkmark$ & & $\checkmark$ & & & $\checkmark$ & $\checkmark$ \\
\hline & Identifying challenges & $\checkmark$ & & & & & & & $\checkmark$ & $\checkmark$ & & \\
\hline & Addressing challenges & & & & & $\checkmark$ & & & & & & \\
\hline & Determining IT requirements & & $\checkmark$ & $\checkmark$ & & & & $\checkmark$ & $\checkmark$ & $\checkmark$ & & $\checkmark$ \\
\hline & Providing BIM training & $\checkmark$ & $\checkmark$ & $\checkmark$ & $\checkmark$ & $\checkmark$ & & & $\checkmark$ & $\checkmark$ & & \\
\hline & Analysis of the current resources & & $\checkmark$ & & & $\checkmark$ & & & & & & \\
\hline & Selecting BIM team and establishing roles & $\checkmark$ & $\checkmark$ & $\checkmark$ & $\checkmark$ & & & $\checkmark$ & & & & \\
\hline & Developing new business model & $\checkmark$ & & & & $\checkmark$ & $\checkmark$ & $\checkmark$ & & & $\checkmark$ & \\
\hline & Determining best practices for BIM & & & & & & & & $\checkmark$ & & & \\
\hline & $\begin{array}{l}\text { Providing financial resources for BIM software } \\
\text { and training }\end{array}$ & & $\checkmark$ & & $\checkmark$ & & & $\checkmark$ & & & & \\
\hline & Analysing improvement/financial gains & & & & & & & & $\checkmark$ & & & \\
\hline \multirow{6}{*}{ 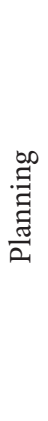 } & Determining areas for BIM implementation & & $\checkmark$ & & $\checkmark$ & & & & & & & $\checkmark$ \\
\hline & $\begin{array}{l}\text { Developing organizational BIM implementation } \\
\text { strategy }\end{array}$ & & $\checkmark$ & & $\checkmark$ & & $\checkmark$ & $\checkmark$ & $\checkmark$ & $\checkmark$ & & $\checkmark$ \\
\hline & $\begin{array}{l}\text { Planning procurement with software vendors and } \\
\text { IT consultants }\end{array}$ & & & & $\checkmark$ & & & & & & & \\
\hline & Documentation of BIM implementation path & & $\checkmark$ & & & & & & & & $\checkmark$ & \\
\hline & $\begin{array}{l}\text { Establishing effective communication between all } \\
\text { stakeholders }\end{array}$ & & & & $\checkmark$ & & & $\checkmark$ & & & & \\
\hline & $\begin{array}{l}\text { Identification of potential risks and ensuring } \\
\text { quality of deliverables }\end{array}$ & & & & $\checkmark$ & & & & & & & \\
\hline \multirow{3}{*}{ 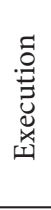 } & $\begin{array}{l}\text { Actual implementation of BIM, it also includes } \\
\text { piloting BIM implementation on projects }\end{array}$ & & $\checkmark$ & & & & $\checkmark$ & $\checkmark$ & $\checkmark$ & & $\checkmark$ & \\
\hline & Creation and coordination of the BIM model & & & & $\checkmark$ & $\checkmark$ & & & & & & \\
\hline & $\begin{array}{l}\text { Monitoring and controlling BIM adoption to } \\
\text { ensure objectives are achieved }\end{array}$ & & $\checkmark$ & & $\checkmark$ & $\checkmark$ & & & & & & \\
\hline \multirow{3}{*}{ 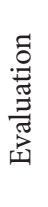 } & Handovers of all BIM deliverables & & & & $\checkmark$ & & & & & & & \\
\hline & $\begin{array}{l}\text { Assessment of project with aim to improve the } \\
\text { implementation approach }\end{array}$ & & $\checkmark$ & & $\checkmark$ & $\checkmark$ & $\checkmark$ & & $\checkmark$ & & & \\
\hline & $\begin{array}{l}\text { Evaluation of BIM implementation project to } \\
\text { outlines the benefits gains from it }\end{array}$ & & & & $\checkmark$ & & $\checkmark$ & & $\checkmark$ & & & \\
\hline
\end{tabular}


Table 3. Factors affecting BIM adoption

\begin{tabular}{|c|c|c|}
\hline \multicolumn{2}{|r|}{ Factors } & References \\
\hline \multirow{4}{*}{ 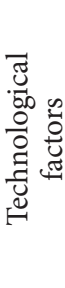 } & Compatibility & $\begin{array}{l}\text { Ngowtanasawan (2016), Ma et al. } \\
\text { (2019), Qin et al. (2020) }\end{array}$ \\
\hline & Complexity & Ahuja et al. (2016), Chen et al. (2019) \\
\hline & Trialability & $\begin{array}{l}\text { Ngowtanasawan (2016), Kim et al. } \\
\text { (2016) }\end{array}$ \\
\hline & $\begin{array}{l}\text { Relative } \\
\text { advantage }\end{array}$ & $\begin{array}{l}\text { Ngowtanasawan (2016), Chen et al. } \\
\text { (2019) }\end{array}$ \\
\hline \multirow{9}{*}{ 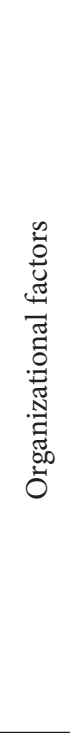 } & $\begin{array}{l}\text { Top } \\
\text { management } \\
\text { support }\end{array}$ & $\begin{array}{l}\text { Lee and Yu (2017), Liao and Teo } \\
\text { (2019), Chen et al. (2019) }\end{array}$ \\
\hline & $\begin{array}{l}\text { Behavioural } \\
\text { intention }\end{array}$ & $\begin{array}{l}\text { Ding et al. (2015), Ngowtanasawan } \\
\text { (2016), Liao and Teo (2019) }\end{array}$ \\
\hline & $\begin{array}{l}\text { Training and } \\
\text { learning }\end{array}$ & $\begin{array}{l}\text { Ngowtanasawan (2016), Liao and Teo } \\
\text { (2019), Ma et al. (2019) }\end{array}$ \\
\hline & Leadership & Liao and Teo (2019), Ma et al. (2019) \\
\hline & Innovativeness & $\begin{array}{l}\text { Eadie et al. (2013), Hong et al. } \\
\text { (2016), Ma et al. (2019) }\end{array}$ \\
\hline & Awareness & $\begin{array}{l}\text { Ngowtanasawan (2016), Hong et al. } \\
\text { (2016), Ma et al. (2019) }\end{array}$ \\
\hline & Motivation & $\begin{array}{l}\text { Ding et al. (2015), Hong et al. (2016), } \\
\text { Cao et al. (2017) }\end{array}$ \\
\hline & Trust & $\begin{array}{l}\text { Ahuja et al. (2016), Liao and Teo } \\
\text { (2019), Ma et al. (2019) }\end{array}$ \\
\hline & $\begin{array}{l}\text { Organizational } \\
\text { culture }\end{array}$ & Liao and Teo (2019), Ma et al. (2019) \\
\hline \multirow{3}{*}{ 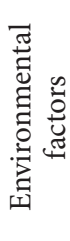 } & Client pressure & $\begin{array}{l}\text { Eadie et al. (2013), Chen et al. } \\
\text { (2019), Ahuja et al. (2016) }\end{array}$ \\
\hline & $\begin{array}{l}\text { Competitive } \\
\text { pressure }\end{array}$ & Eadie et al. (2013), Chen et al. (2019) \\
\hline & $\begin{array}{l}\text { Partner } \\
\text { pressure }\end{array}$ & Chen et al. (2019), Ahuja et al. (2016) \\
\hline
\end{tabular}

As a public authority, TCG is responsible for issuing building permits, certificates of occupancy and demolition permits in the area of administration of Tallinn city. In 2019, approximately 1800 building permits and 1500 certificates of occupancy are issued. A number of departments are involved in the permits issuing process as shown in Figure 1 lead by the City Planning department. The current work process suffers from issues of intricacy, inaccuracy and inefficiency and TCG is adopting BIM for building permits in order to improve the work process, increase collaboration among different departments and effectively respond to time and cost pressures.

The BIM adoption process by TCG is presented in the following sections in accordance with the generic BIM adoption process developed from the literature (and shown in Table 2).

\subsection{Initiation}

\section{Reviewing organization current situation and practices}

Currently, the permitting process by TCG is still being done manually and consists of uploading PDF format documents and 2D drawings. After the submission, the documents are reviewed by city planning officials, comparing their compliance with laws, regulations and standards. There is a huge amount of complex regulatory material but no central database where that information could be stored and made visible for all the stakeholders in the permit issuing process. This makes the flow of information slow within the building permit process. Co-ordination information between different departments is exchanged via e-mail and telephone. Interviews with TCG officials indicate that many working hours are used in finding necessary information about the project, which makes it a lengthy process and subject to human error.

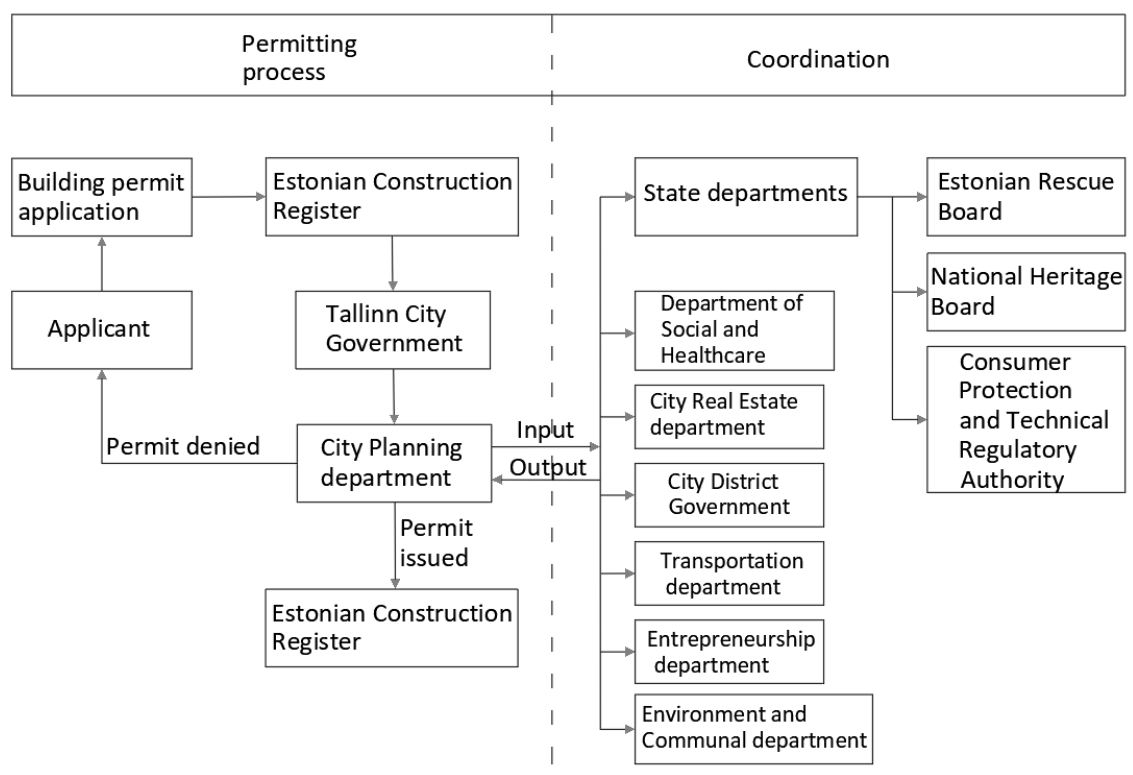

Figure 1 . The structure of Tallinn City Government in building permitting process 


\section{Defining objectives of the organization for adopting BIM}

The objective of BIM adoption by TCG is to simplify and improve the process and issuing of building permits. The current focus of the organization is on BIM model-based permit issuing in the form of: Building permit, issued based on preliminary BIM project (IFC format); certificate of occupancy, issued based on as-built BIM project (IFC format); demolition permit, based on demolition BIM project (format not yet classified). Nevertheless, design criteria for the model in the phase of detailed planning must also be included as, without BIM adoption for design criteria, full implementation of other described objectives is not possible.

\section{Identifying and addressing challenges}

TCG has several challenges regarding its BIM adoption process. These challenges can be divided into three main groups: organizational structure related, workforce qualification related and hardware-software related challenges. The last challenge can also be addressed as determining IT requirements.

The organizational structure needs to be analysed and adjusted accordingly to support the BIM adoption process. Guidance materials and a permit issuing checklist must be created to standardise process outcomes.

Workforce qualification needs to be enhanced for a BIM based building permitting process. Most TCG officials have to go through a BIM training program for creating BIM awareness and learning to use necessary BIM tools. An extra position of BIM coordinator in the Tallinn City Planning Department has to be created because training cannot provide sufficient skill levels for the current workforce to coordinate the BIM adoption process.

The difficulty level of the hardware-software challenge for TCG is still unknown. TCG is in cooperation with the
Estonian Ministry of Economic Affairs and Communications (MoEAC) in this BIM adoption process. MoEAC will provide the digital environment to store BIM projects and cloud-based software working on open BIM standards for permit issuing to TCG and other Estonian municipalities. Therefore, the necessity for high end computers and large-scale BIM software (Autodesk, Graphisoft, Solibri, Tekla etc.) is very low. Only the BIM coordinator has the need for an upgraded IT solution. Detailed software packages will be determined at a later stage of this BIM adoption process.

\section{Providing BIM training}

Three different types of BIM training have been provided to TCG employees. Basic BIM training has been delivered twice, advanced BIM training once and BIM Model Checks (BMC) training five times. The purpose of basic BIM training was to create awareness about BIM and its benefits in AEC/FM industry. Advanced BIM training focused on the nature of BIM and global case studies. BMC training courses were provided as a training series consisting of working with BIM models from the perspective of the building permit issuer and using Solibri Model Checker (SMC) software. SMC was selected as a result of the software solution provided by the MoEAC being incomplete. That solution is currently in Proof of Concept (POC) phase.

\section{Analyses of processes related with BIM adoption in the organization}

In order to implement the BIM adoption successfully, several sub-processes (subsurface data analyses, regulatory and legal analyses, developing standards and norms, etc.) need to be in place. The processes necessary for BIMbased building permitting are shown in Figure 2. The centre of all these processes is the e-construction platform

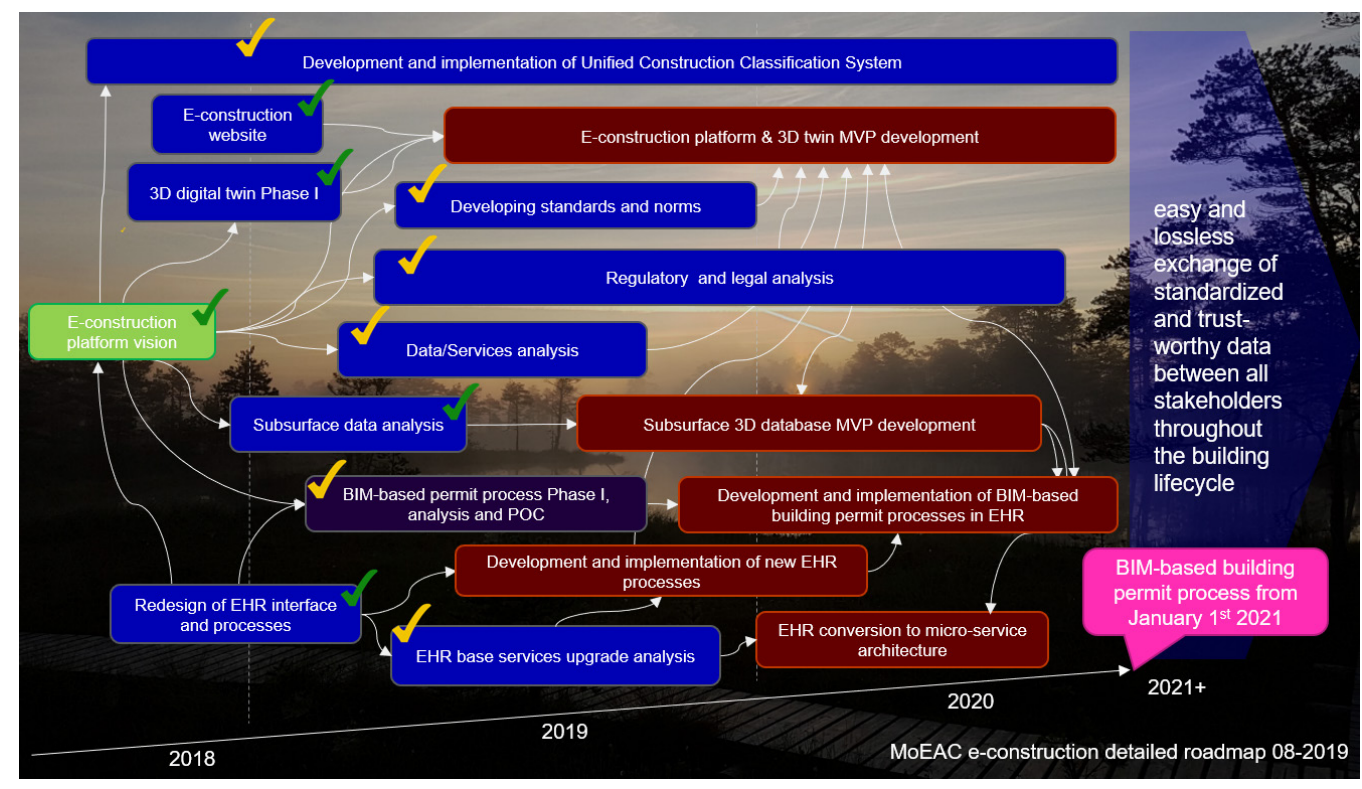

Figure 2. MoEAC detailed roadmap for BIM-based building permit process (source: Estonian Ministry of Economic Affairs and Communication) 
provided by the MoEAC where all construction related information will be stored. Processes shown in Figure 2 with green ticks have been completed, while processes with yellow ticks are ongoing but not yet finished. Processes shown with a red background are planned but have not yet started.

\section{Developing new business model}

For successful BIM adoption, a new business model for the organization must be developed. This business model, based on BIM for TCG, is described in Figure 3. The primary task for TCG is to map the functions of the departments involved in the permit issuing process. Completion of that task enables the creation of detailed checklists for comparing relevant application project parameters against the national building code. IFC format minimum requirements for permit issuing emerge from that checklist. Additionally, an effective IT solution for automated BMC can only be determined once the checklists have been developed.

Automated BIM Model checking is possible if the submitted BIM project is standardised. Therefore, it is necessary to create national BIM standards for designers. These standards must include IFC format minimum requirements, national classification system (CoClass for this case study) and LOD specification for the BIM elements in specific project phases. If these requirements are met, then the new business model can be implemented.

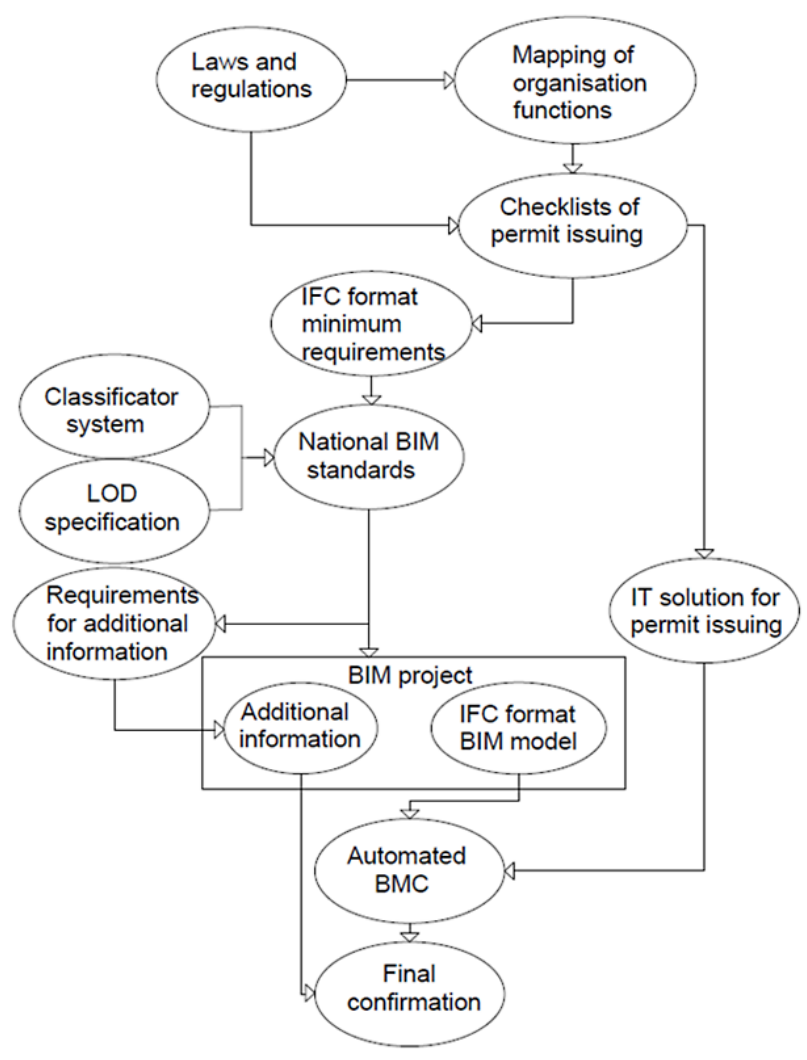

Figure 3. New business model of TCG for BIM-based permit issuing

\section{Providing financial resources for BIM software and training}

TCG is funded by taxpayers and has a stable financial income. Budgetary decisions are made once a year, meaning no sudden allocation of non-emergency financial resources is possible. TCG has financial resources for BIM training within its budget. If BIM software packages or extra personnel are required, application for necessary funds must be made on time. The need for extra financial resources is, as yet, unclear as the software solution is to be provided by MoEAC, but this is still in an early (POC) phase of development. If the need for financial resources arises, these are likely to be allocated as the Mayor of Tallinn is highly supportive of BIM adoption in TCG.

\section{Analysing improvement/financial gains}

Rough estimates of potential savings have been made based on the average time spent processing permits in TCG. The averages shown in Table 4 were collected from interviews with TCG officials. Based on a notional timesaving of $60 \%$ and an average hourly wage of $11 €$ in Estonia, the potential savings per year are $181,587 €$ for the building permit and certificate of occupancy. This calculation assumes estimated savings for simple buildings would be lower $(40 \%)$ than for complex buildings $(80 \%)$ since the automatic checks will be much more helpful for the complex buildings.

Interviews with TCG permit issuing officials and the stakeholder consultation suggest that actual savings could be significantly higher. In addition, this calculation only considers the building permit and certificate of occupancy. There are more permits and processes which will benefit from an automated BMC solution.

Table 4. Rough estimates of financial gains from BIM adoption in TCG

\begin{tabular}{|c|c|c|c|c|c|}
\hline & 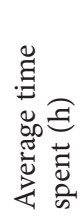 & 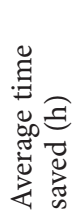 & 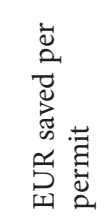 & 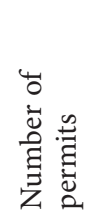 & 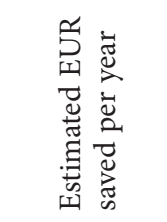 \\
\hline $\begin{array}{l}\text { Building } \\
\text { permit }\end{array}$ & & & & 1822 & $98,176.58 €$ \\
\hline $\begin{array}{l}\text { Simple } \\
\text { building }\end{array}$ & 7.3 & 1.8 & $19.27 €$ & 947 & $18,250.58 €$ \\
\hline $\begin{array}{l}\text { Complex } \\
\text { building }\end{array}$ & 17.3 & 8.3 & $91.34 €$ & 875 & $79,926.00 €$ \\
\hline $\begin{array}{l}\text { Cert. of } \\
\text { occupancy }\end{array}$ & & & & 1550 & $83,410.27 €$ \\
\hline $\begin{array}{l}\text { Simple } \\
\text { building }\end{array}$ & 7.4 & 1.8 & $19.54 €$ & 888 & $17,347.97 €$ \\
\hline $\begin{array}{l}\text { Complex } \\
\text { building }\end{array}$ & 18.9 & 9.1 & $99.79 €$ & 662 & $66,062.30 €$ \\
\hline Total saving & & & & & $181,586.86 €$ \\
\hline
\end{tabular}




\subsection{Planning}

\section{Determining areas for BIM implementation}

The most beneficial area for BIM implementation to TCG is the process of permit issuing. This will enable TCG to automate this process in the long term and make the permit issuing process cost-effective in the short term. In addition to saving time and financial resources, BIM adoption in the permit issuing process enables the collection of data for creating a digital twin of Tallinn city.

Developing organizational BIM implementation strategy and documentation of BIM implementation path

The BIM implementation strategy for TCG has been formulated and is being documented in cooperation with a local university. In the time period 2019-2020 proof of concept, user experience and user interface are to be created and piloted. Simultaneously, BIM training for TCG officials involved in the BIM adoption process is delivered. In 2021, the BIM-based permitting process will be operational. The focus then shifts to correcting any evident flaws in the process and creating an automatic regulation-linked update system. In addition, initiation of BIM adoption for FM starts. In 2022 BIM adoption for FM will reach the planning phase and evaluation of BIM adoption for permit issuing will be finalised and conclusions for further action drawn.

\section{Planning procurement with software vendors and IT consultants}

The primary software needed for BIM-based permit issuing will be provided to TCG by the MoEAC. This software, created by MoEAC in collaboration with TCG, is without direct cost for TCG. IT consultation regarding the use of the software will also be provided to TCG by MoEAC. However, procurement of IT consultants for adjusting the information flows between the software and different departments of TCG, is planned to be outsourced to the private sector.

\section{Establishing effective communication between all stakeholders}

The main purpose of BIM-based permit processing is to create a convenient and secure exchange of standardized and accurate data between all stakeholders throughout the building lifecycle. For ensuring the effectiveness of communication, MoEAC is creating an e-construction platform (referred to in Figure 2) through which all information through the building lifecycle will be communicated. Furthermore, it will store the guidance information, legislation, regulations and standards required for specific procedures.

Identification of potential risks and ensuring quality of deliverables

A large number of different systems and organizations involved in permit issuing need to ensure simultaneous BIM adoption in the environment created by the MoEAC. For example, BIM adoption for permit issuing involves running an automated BMC for a BIM project in IFC format against the spatial planning concerning that building. The BIM project must meet criteria set by detailed area plans, which are still in non-BIM-compatible file formats so, until digitalization of area planning, BIM adoption cannot be complete. Similarly, the connections between building projects and the infrastructure networks of the city pose risks as water, heating and electrical network connections are controlled by private sector companies whose level of BIM adoption is variable.

\subsection{Execution}

\section{Pilot BIM implementation project}

The first step of BIM implementation is a joint pilot project between TCG and the MoEAC. The MoEAC is developing the Proof of Concept (POC) for the permit issuing software. Piloting is carried out on a BIM project of an apartment complex located in Tallinn. For this project, all the necessary documents, including the detailed spatial plan in CityGML format, is provided and coordinated by TCG. Consultation of TCG BIM implementation process is provided by a local university.

The POC (see Figure 4) is based on the use of open standards: IFC, CityGML and BCF, and also visualisation standards like WebGL 2. On request from the MoEAC, the React JavaScript framework is used. Everything is based on open buildingSMART and W3C guidelines and standards.

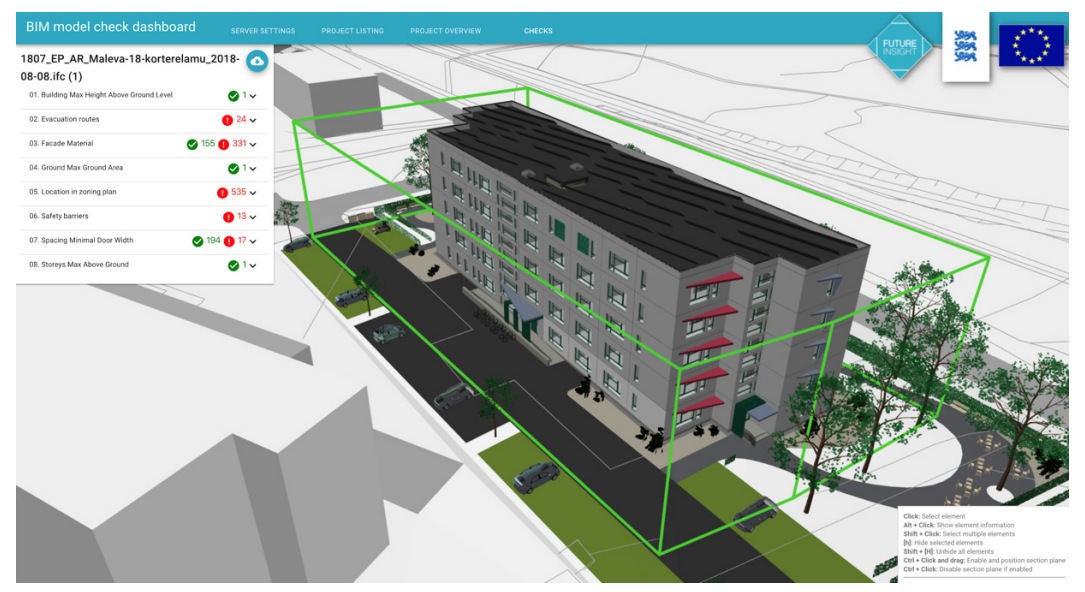

Figure 4. The interface of POC (source: Estonian Ministry of Economic Affairs and Communications) 
When an IFC dataset is checked in, it is sent to a BIM server. After check-in, the geometry is calculated by the IfcOpenShell plugin running inside BIMserver. Results of that are being stored in the BIM server database. The next step is that the geometry is sent to the Voxel server for voxelization and further analyses. Results of the analyses are stored as 'extended data' in BIMserver.

Finally, the data is streamed back to the GUI for visualisation. 3D information is streamed in binary format to visualise in BIM Surfer. Text data is shown using the React framework which is also used for the implementation of the new building registry system.

\section{Coordination of the BIM model between all disciplines}

In spite of the fact that TCG is not involved in the design phase of the BIM model, coordination between all disciplines is still essential due to the complex structure of TCG departments (refer to Figure 1). Every department must collect data from different aspects of the construction project documentation, in this case from a certain discipline-specific BIM model. The BIM coordinator extracts the information needed by the permit issuer from the BIM model and an automated BMC checks that information against the regulatory requirements. In addition, correct coordination of the BIM model between all disciplines is necessary in the design phase before the BIM model is submitted for permit issuing. Coordination failures can render automated BMC impossible.

\section{Monitoring and controlling BIM adoption to ensure objectives are achieved}

TCG has an ongoing contract with a local university for monitoring their BIM adoption process. The achievement of objectives is monitored and controlled through weekly meetings, reports and working groups. Furthermore, a BIM coordinator position will soon be created within TCG allowing for correct evaluation and to continue the work done by the consultants from the local university.

\subsection{Evaluation}

The BIM adoption process in TCG is still in the execution phase. Therefore, evaluation is not yet feasible. Once execution is achieved to a greater extent, the BIM coordinator or a manager of TCG will be able to carry out evaluation tasks, point out shortcomings, analyse benefits of BIM adoption and offer recommendations for necessary corrections.

\subsection{Factors affecting BIM adoption in TCG}

During interviews, the TCG officials were asked about factors affecting their BIM adoption process (At this stage of the study no attempt was made to measure the relative impact of the factors). Table 5 illustrates the factors BIM adoption process in TCG.

Table 5. Factors affecting BIM adoption in TCG

\begin{tabular}{|c|c|c|}
\hline \multicolumn{2}{|r|}{ Factors } & Comments from interviewees \\
\hline \multirow{4}{*}{ 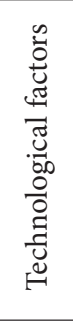 } & Compatibility & $\begin{array}{l}\text { The new BIM based permit process needs to be compatible with the building registry and with the } \\
\text { new e-construction platform }\end{array}$ \\
\hline & Complexity & $\begin{array}{l}\text { Complexity of BIM tools affects BIM adoption; however, it is expected that the building permit } \\
\text { process will become more efficient with BIM }\end{array}$ \\
\hline & Trialability & $\begin{array}{l}\text { The piloting in the execution phase offers the opportunity to try out the BIM based system before using } \\
\text { it in real work. The positive impact of trialability is observed in the overall BIM adoption process }\end{array}$ \\
\hline & Relative advantage & $\begin{array}{l}\text { Relative advantage is among the main drivers for BIM adoption by TCG as it is expected that the } \\
\text { new system will offer potential savings in time and cost and would be more efficient }\end{array}$ \\
\hline \multirow{8}{*}{ 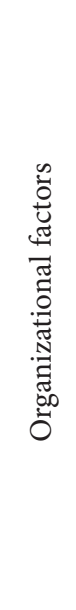 } & $\begin{array}{l}\text { Top management } \\
\text { support }\end{array}$ & $\begin{array}{l}\text { Strong support is provided by top management of TCG towards BIM adoption from the initial } \\
\text { stage, thus it has a positive impact }\end{array}$ \\
\hline & Training and learning & $\begin{array}{l}\text { Intensive BIM training programs are offered to TCG employees (dealing with building permits) for } \\
\text { creating BIM awareness and learning to use the necessary BIM tools }\end{array}$ \\
\hline & Leadership & $\begin{array}{l}\text { TCG is a municipal level organization, the local mayor is strongly supportive towards BIM adop- } \\
\text { tion in TCG }\end{array}$ \\
\hline & Innovativeness & $\begin{array}{l}\text { Organizational innovativeness is observed in the form of the initial decision by TCG top manage- } \\
\text { ment to adopt BIM for building permits instead of continuing with current traditional practice }\end{array}$ \\
\hline & Awareness & $\begin{array}{l}\text { In the beginning of the BIM adoption process (2018) many TCG employees were not aware of BIM use } \\
\text { for building permits. However, training programs were very useful for creating awareness about BIM }\end{array}$ \\
\hline & Motivation & Various perceived advantages in using BIM tools motivated TCG officials to adopt BIM \\
\hline & Trust & $\begin{array}{l}\text { There was an issue of trust on BIM tools - to what extent this new BIM based building permitting } \\
\text { process would be useful after full adoption of BIM }\end{array}$ \\
\hline & Organizational culture & $\begin{array}{l}\text { In the beginning (2018) there was some resistance towards BIM adoption, however, with the training } \\
\text { programs, this has been addressed and the organizational culture is supportive of BIM adoption }\end{array}$ \\
\hline \multirow{3}{*}{ 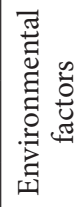 } & Client pressure & $\begin{array}{l}\text { The traditional building permits process was time consuming, thus there was a pressure to move } \\
\text { towards a more efficient process }\end{array}$ \\
\hline & Competitive pressure & $\begin{array}{l}\text { In general, there was no such competitive pressure on TCG. However, the BIM based process in } \\
\text { Singapore and some Scandinavian countries were motivational towards BIM adoption by TCG }\end{array}$ \\
\hline & Partner pressure & There was no partner pressure on TCG towards BIM adoption \\
\hline
\end{tabular}




\section{Conclusions}

The objective of this paper was to investigate the BIM adoption process in the AEC/FM industry and, specifically with regard to building permits issuing by public authorities. BIM enabled building permits is an emerging area of research as a result there are limited studies available on BIM use for building permits. To gain a broad understanding of BIM adoption processes and the factors that affect them, a systematic literature review on BIM adoption in the AEC/FM industry was carried out.

From content analysis of existing studies, a generic model BIM adoption process was derived with four stages: initiation, planning, execution and evaluation and each stage further elaborated by detailed steps. In addition, all the factors affecting the BIM adoption process revealed in the extant literature were collated and classified on the basis of the Technology, Organization and Environment (TOE) framework. Together, the generic BIM adoption process and classification of factors affecting it provided an analytical framework with which to examine and understand the BIM adoption process in the case of Tallinn City Government (TCG).

The TCG case study showed that, after the initial steps and planning, the TCG is now implementing a pilot project and can be considered to be in an execution stage of its BIM adoption process. Organizational review is essential to determine the available resources and establishing clear objectives of BIM adoption. The case study shows that a well-defined implementation strategy is required for successful BIM adoption. The case study confirms that training programmes are critical for BIM adoption. As the BIM adoption in TCG is currently in the pilot part of the execution stage, the piloting can assist in improving the designed new business model for BIM enabled building permits. Once the execution stage is completed the evaluation stage will be performed which is critical for improving the process and assessment of the overall BIM adoption process. The case study showed that, for successful BIM adoption, both technical and non-technical factors are important. Trialability, relative advantage, top management support, and organizational awareness were considered to have a positive effect on BIM adoption. Although, the analytical framework (generic BIM adoption process and factors affecting BIM adoption) was derived from studies focused on more general BIM adoption processes in the AEC/FM industry, it was found to be practically applicable to investigating BIM adoption by a specific organization dealing with building permits. In addition, it has the potential to be applied for studying the BIM adoption process in other organizations in AEC/FM industry. Meanwhile, the developed model shown in Figure 3 for BIM enabled building permits process can also provide guidance to other organizations that plan to adopt BIM for issuing building permits.

Whereas this study has provided an overview of the BIM adoption process at TCG and identified factors affecting it, future studies will aim to explore these factors affecting BIM adoption in public organizations to a greater depth. It is also notable that the specific challenges in relation to BIM adoption for the purpose of processing building permits call for further investigation and, once the TCG nears completion of the execution stage, opportunities for investigating the value of a BIM based building permitting process in terms of cost, time and efficiency perspectives will arise.

\section{Acknowledgements}

This research was supported by the Tallinn City Government and "Integrating Education with Consumer Behaviour relevant to Energy Efficiency and Climate Change at the Universities of Russia, Sri Lanka and Bangladesh (BECK)" project No. 598746-EPP-1-2018-1-LT-EPPKA2CBHE-JP, Grant Agreement No. 2018-2489/001-001 cofunded by the Erasmus+ Programme of the European Union. The European Commission support for the production of this publication does not constitute an endorsement of the contents which reflects the views only of the authors, and the Commission cannot be held responsible for any use which may be made of the information contained therein.

\section{Disclosure statement}

No potential conflict of interest.

\section{References}

Ahmed, A. L., \& Kassem, M. (2018). A unified BIM adoption taxonomy: conceptual development, empirical validation and application. Automation in Construction, 96, 103-127. https://doi.org/10.1016/j.autcon.2018.08.017

Ahn, Y. H., Kwak, Y. H., \& Suk, S. J. (2016). Contractors' transformation strategies for adopting building information modeling. Journal of Management in Engineering, 32(1). https://doi.org/10.1061/(ASCE)ME.1943-5479.0000390

Ahuja, R., Jain, M., Sawhney, A., \& Arif, M. (2016). Adoption of BIM by architectural firms in India: technology-organizationenvironment perspective. Architectural Engineering and Design Management, 12(4), 311-330.

https://doi.org/10.1080/17452007.2016.1186589

Almuntaser, T., Sanni-Anibire, M. O., \& Hassanain, M. A. (2018). Adoption and implementation of BIM - case study of a Saudi Arabian AEC firm. International Journal of Managing Projects in Business, 11(3), 608-624.

https://doi.org/10.1108/IJMPB-05-2017-0046

Arayici, Y., Coates, P., Koskela, L., Kagioglou, M., Usher, C., \& O'Reilly, K. (2011). BIM adoption and implementation for architectural practices. Structural Survey, 29(1), 7-25. https://doi.org/10.1108/02630801111118377

Bearman, M., Smith, C. D., Carbone, A., Slade, S., Baik, C., Hughes-Warrington, M., \& Neumann, D. L. (2012). Systematic review methodology in higher education. Higher Education Research \& Development, 31(5), 625-640. https://doi.org/10.1080/07294360.2012.702735

Chen, Y., Yin, Y., Browne, G. J., \& Li, D. (2019). Adoption of building information modeling in Chinese construction industry: the technology-organization-environment frame- 
work. Engineering, Construction and Architectural Management, 26(9). https://doi.org/10.1108/ECAM-11-2017-0246

Chunduri, S., Kreider, R., \& Messner, J. I. (2013). A case study implementation of the BIM planning procedures for facility owners. In AEI 2013: Building Solutions for Architectural Engineering (pp. 691-701).

https://doi.org/10.1061/9780784412909.068

Davis, F. D. (1989). Perceived usefulness, perceived ease of use, and user acceptance of information technology. MIS Quarterly, 13(3), 319-340. https://doi.org/10.2307/249008

Ding, Z., Zuo, J., Wu, J., \& Wang, J. Y. (2015). Key factors for the BIM adoption by architects: a China study. Engineering, Construction and Architectural Management, 22(6), 732-748. https://doi.org/10.1108/ECAM-04-2015-0053

Eadie, R., Odeyinka, H., Browne, M., Mckeown, C., \& Yohanis, M. (2013). An analysis of the drivers for adopting building information modelling. Journal of Information Technology in Construction (ITcon), 18, 338-352.

Eika, A. (2019). Urban development and cooperation games. Journal of Property Research, 36(3), 291-311. https://doi.org/10.1080/09599916.2019.1615977

Eirinaki, M., Dhar, S., Mathur, S., Kaley, A., Patel, A., Joshi, A., \& Shah, D. (2018). A building permit system for smart cities: a cloud-based framework. Computers, Environment and Urban Systems, 70, 175-188. https://doi.org/10.1016/j.compenvurbsys.2018.03.006

Franz, B., \& Messner, J. (2019). Evaluating the impact of Building Information Modeling on project performance. Journal of Computing in Civil Engineering, 33(3), 04019015. https://doi.org/10.1061/(ASCE)CP.1943-5487.0000832

Gerring, J. (2004). What is a case study and what is it good for? The American Political Science Review, 98(2), 341-354. https://doi.org/10.1017/S0003055404001182

Gledson, B. J., \& Greenwood, D. (2017). The adoption of 4D BIM in the UK construction industry: an innovation diffusion approach. Engineering Construction and Architectural Management, 24(6), 950-967.

https://doi.org/10.1108/ECAM-03-2016-0066

Gough, D. (2007). Weight of evidence: a framework for the appraisal of the quality and relevance of evidence. Research $\mathrm{Pa}$ pers in Education, 22(2), 213-228.

https://doi.org/10.1080/02671520701296189

Gu, N., \& London, K. (2010). Understanding and facilitating BIM adoption in the AEC industry. Automation in Construction, 19(8), 988-999. https://doi.org/10.1016/j.autcon.2010.09.002

Gudienè, N., Banaitis, A., Banaitienè, N., \& Lopes, J. (2013). Development of a conceptual critical success factors model for construction projects: a case of Lithuania. Procedia Engineering, 57, 392-397. https://doi.org/10.1016/j.proeng.2013.04.051

Gudienè, N., Banaitis, A., Podvezko, V., \& Banaitienè, N. (2014). Identification and evaluation of the critical success factors for construction projects in Lithuania: AHP approach. Journal of Civil Engineering and Management, 20(3), 350-359. https://doi.org/10.3846/13923730.2014.914082

Gurevich, U., Sacks, R., \& Shrestha, P. (2017). BIM adoption by public facility agencies: impacts on occupant value. Building Research \& Information, 45(6), 610-630. https://doi.org/10.1080/09613218.2017.1289029

Hameed, M. A., Counsell, S., \& Swift, S. (2012). A conceptual model for the process of IT innovation adoption in organizations. Journal of Engineering and Technology Management, 29(3), 358-390.

https://doi.org/10.1016/j.jengtecman.2012.03.007
Hardin, B. (2009). BIM and construction management: proven tools, methods and workflows. Wiley Publishing, Inc.

Hochscheid, E., \& Halin, G. (2018). BIM implementation in architecture firms interviews, case studies and action research used to build a method that facilitates implementation of BIM processes and tools. In 36th ECAADe Annual Conference. Lodz, Poland.

Hochscheid, E., \& Halin, G. (2019). A framework for studying the factors that influence the BIM adoption process. In 36th CIB W78, ICT in Design, Construction and Management in Architecture, Engineering, Construction and Operations. Newcastle.

Hong, Y., Sepasgozar, S. M. E., Ahmadian, A. F. F., \& Akbarnezhad, A. (2016). Factors influencing BIM adoption in small and medium sized construction organizations. In 33rd International Symposium on Automation and Robotics in Construction (ISARC 2016) (pp. 452-461). https://doi.org/10.22260/ISARC2016/0055

Husain, A. H., Razali, M. N., \& Eni, S. (2018). Stakeholders' expectations on building information modelling (BIM) concept in Malaysia. Property Management, 36(4), 400-422. https://doi.org/10.1108/PM-02-2017-0013

International Code Council. (2018). International Building Code. New Jersey.

Khosrowshahi, F., \& Arayici, Y. (2012). Roadmap for implementation of BIM in the UK construction industry. Engineering, Construction and Architectural Management, 19(6), 610-635. https://doi.org/10.1108/09699981211277531

Kildienè, S., Kaklauskas, A., \& Zavadskas, E. K. (2011). COPRAS based comparative analysis of the European country management capabilities within the construction sector in the time of crisis. Journal of Business Economics and Management, 12(2), 417-434. https://doi.org/10.3846/16111699.2011.575190

Kim, S., Park, C. H., \& Chin, S. (2016). Assessment of BIM acceptance degree of Korean AEC participants. KSCE Journal of Civil Engineering, 20(4), 1163-1177.

https://doi.org/10.1007/s12205-015-0647-y

Kitchenham, B., \& Charters, S. (2007). Guidelines for performing systematic literature reviews in software engineering (Version 2.3, Technical Report). Software Engineering Group, Keele University and Department of Computer Science, University of Durham.

Kouch, A. M. (2018). A three-step BIM implementation framework for the SME contractors. In C. Fortin, L. Rivest, A. Bernard, \& A. Bouras (Eds.), IFIP advances in information and communication technology: Vol. 540. Product lifecycle management to support industry 4.0 (pp. 15-24). Springer. https://doi.org/10.1007/978-3-030-01614-2_2

Krajewska, M., Źróbek, S., \& Kovač, M. Š. (2014). The role of spatial planning in the investment process in Poland and Slovenia. Real Estate Management and Valuation, 22(2), 52-66. https://doi.org/10.2478/remav-2014-0017

Lee, S., \& Yu, J. (2017). Discriminant model of BIM acceptance readiness in a construction organization. KSCE Journal of Civil Engineering, 21(3), 555-564. https://doi.org/10.1007/s12205-016-0555-9

Leśniak, A., Górka, M., \& Kargol, A. (2019). Analysis of errors in investors' applications in the procedure of obtaining a building permit. Civil and Environmental Engineering Reports, 29(4), 185-197. https://doi.org/10.2478/ceer-2019-0054

Liao, L., \& Teo, E. A. L. (2019). Managing critical drivers for building information modelling implementation in the Singapore construction industry: an organizational change perspective. 
International Journal of Construction Management, 19(3), 240256. https://doi.org/10.1080/15623599.2017.1423165

Lin, Y.-C., Chen, Y.-P., Huang, W.-T., \& Hong, C.-C. (2016). Development of BIM execution plan for BIM model management during the pre-operation phase: a case study. Buildings, 6(1), 8. https://doi.org/10.3390/buildings6010008

Ma, G., Jia, J., Ding, J., Shang, S., \& Jiang, S. (2019). Interpretive structural model based factor analysis of BIM adoption in Chinese construction organizations. Sustainability, 11(7), 1982. https://doi.org/10.3390/su11071982

Machado, M., Underwood, J., \& Fleming, A. (2016). Implementing BIM to streamline a design, manufacture, and fitting workflow: a case study on a fit-out SME in the UK. International Journal of 3-D Information Modeling, 5(3), 31-46. https://doi.org/10.4018/IJ3DIM.2016070103

Meulen, P. De, Micheli, M., \& Schmidt, T. (2014). Forecasting real estate prices in Germany: the role of consumer confidence. Journal of Property Research, 31(3), 244-263. https://doi.org/10.1080/09599916.2014.940059

Narayanswamy, H., Liu, H., \& Al-Hussein, M. (2019). BIM-based automated design checking for building permit in the lightframe building industry. In 36th International Symposium on Automation and Robotics in Construction. Alberta. https://doi.org/10.22260/ISARC2019/0139

Nawari, N. O., \& Alsaffar, A. (2017). The role of BIM in simplifying construction permits in Kuwait. Resilience of the integrated building. In Proceedings of the Architectural Engineering National Conference 2017 (pp. 855-866). https://doi.org/10.1061/9780784480502.072

Ngowtanasawan, G. (2016). A causal model of BIM adoption in the Thai architectural and engineering design industry. Procedia Engineering, 180(4), 793-803. https://doi.org/10.1016/j.proeng.2017.04.240

Olsson, P.-O., Axelsson, J., Hooper, M., \& Harrie, L. (2018). Automation of building permission by integration of BIM and geospatial data. ISPRS International Journal of Geo-Information, 7(8), 307. https://doi.org/10.3390/ijgi7080307

Ozener, O. O., Tezel, E., Kilic, Z. A., \& Akdogan, M. (2020). Trends of building information modeling adoption in the Turkish AEC industry. In S. Ofluoglu, O. Ozener, \& U. Isikdag (Eds.), Communications in computer and information science: Vol. 1188. Advances in building information modeling (pp. 3-14). Springer. https://doi.org/10.1007/978-3-030-42852-5_1

Project Management Institute Standards Committee. (2013). Guide to the Project Management Body of Knowledge (PMBOK Guide, 5th ed.). Project Management Institute.

Qin, X., Shi, Y., Lyu, K., \& Mo, Y. (2020). Using a TAM-TOE model to explore factors of Building Information Modelling
(BIM) adoption in the construction industry. Journal of Civil Engineering and Management, 26(3), 259-277. https://doi.org/10.3846/jcem.2020.12176

Rivera, F. M.-L., Vielma, J. C., Herrera, R. F., \& Carvallo, J. (2019). Methodology for Building Information Modeling (BIM) implementation in structural engineering companies (SECs). Advances in Civil Engineering, 2019, 1-16. https://doi.org/10.1155/2019/8452461

Robson, C. (2002). Real world research: a resource for social scientists and practitioner-researchers (2nd ed.). Blackwell.

Rogers, E. M. (1983). Diffusion of innovations (3rd ed.). Free Press.

Samsura, D. A. A., Krabben, E. van der, Deemen, A. M. A. van, \& Heijde, R. E. C. M. van der. (2015). Negotiation processes in land and property development: an experimental study. Journal of Property Research, 32(2), 173-191. https://doi.org/10.1080/09599916.2015.1009846

Sanchís-Pedregosa, C., Vizcarra-Aparicio, J. M., \& Leal-Rodríguez, A. L. (2020). BIM: a technology acceptance model in Peru. Journal of Information Technology in Construction, 25, 99-108. https://doi.org/10.36680/j.itcon.2020.006

Shibeika, A., \& Harty, C. (2015). Diffusion of digital innovation in construction: a case study of a UK engineering firm diffusion of digital innovation in construction: a case study of a UK engineering firm. Construction Management and Economics, 33(5-6), 453-466.

https://doi.org/10.1080/01446193.2015.1077982

Sodangi, M. (2019). Building information modelling-development and validation of implementation framework for improving performance of subcontractors. Lecture Notes in Civil Engineering, 9, 393-405. https://doi.org/10.1007/978-981-10-8016-6_31

Son, H., Lee, S., Hwang, N., \& Kim, C. (2014). The adoption of building information modeling in the design organization: an empirical study of architects in Korean design firms. In 31st International Symposium on Automation and Robotics in Construction and Mining (ISARC 2014). https://doi.org/10.22260/ISARC2014/0026

Tornatzky, L. G., Fleischer, M., \& Chakrabarti, A. K. (1990). The process of technological innovation. Lexington Books.

Whyte, J. K., \& Hartmann, T. (2017). How digitizing building information transforms the built environment. Building Research \& Information, 45(6), 591-595. https://doi.org/10.1080/09613218.2017.1324726

Xu, H., Feng, J., \& Li, S. (2014). Users-orientated evaluation of building information model in the Chinese construction industry. Automation in Construction, 39, 32-46. https://doi.org/10.1016/j.autcon.2013.12.004 